\title{
OPEN Author Correction: Chemokines as the modulators of endometrial epithelial cells remodelling
}

\section{A. Złotkowska \& A. Andronowska}

Correction to: Scientific Reports https://doi.org/10.1038/s41598-019-49502-5, published online 10 September 2019

The Acknowledgements section in this Article is incomplete.

"This study was supported by statutory activity of Institute of Animal Reproduction and Food Research of Polish Academy of Sciences in Olsztyn, Poland."

should read:

“This study was supported by statutory activity of Institute of Animal Reproduction and Food Research of Polish Academy of Sciences in Olsztyn, Poland. The article processing charge was covered by the KNOW Consortium: "Healthy Animal - Safe Food" (Ministry of Sciences and Higher Education; Dec: 05-1/KNOW2/2015)."

(c) (i) Open Access This article is licensed under a Creative Commons Attribution 4.0 International Cicense, which permits use, sharing, adaptation, distribution and reproduction in any medium or format, as long as you give appropriate credit to the original author(s) and the source, provide a link to the Creative Commons license, and indicate if changes were made. The images or other third party material in this article are included in the article's Creative Commons license, unless indicated otherwise in a credit line to the material. If material is not included in the article's Creative Commons license and your intended use is not permitted by statutory regulation or exceeds the permitted use, you will need to obtain permission directly from the copyright holder. To view a copy of this license, visit http://creativecommons.org/licenses/by/4.0/.

(C) The Author(s) 2019

Department of Hormonal Action Mechanisms, Institute of Animal Reproduction and Food Research of the Polish Academy of Sciences, Olsztyn, Poland. Correspondence and requests for materials should be addressed to A.A. (email: a.andronowska@pan.olsztyn.pl) 